\title{
A Student Perspective on Contract Grading
}

\author{
Taylor Lucas, BA in English \\ Park University
}

When I was a senior in high school, I enrolled in a first-year college writing course. Our assignments included the typical essays, like a personal narrative, an expository essay, and a media criticism analysis paper. I loved writing, but the class was daunting; the grade I earned in this course would go on my college transcripts before I'd even chosen a college to attend. To ensure I maintained good grades and met the requirements for every paper, I wrote two essays per assignment. Every due date, I asked my teacher to read both and help me choose the stronger paper. Every due date, she refused. "Turn in the one you like better," she always told me. The problem was that I didn't care about which one I liked better; I cared about turning in the one my teacher would like better because I was trying to earn an A in the course. (In case you're wondering what my first course grade ended as, I did get the A.)

It wasn't until my sophomore year of college that I realized what it meant to write and submit an assignment because I liked it, not because I thought it was what my professor wanted. The course that helped me discover my writing style was called Introduction to English Studies (EN205), and it was the first class in which the syllabus used contract grading, also commonly referred to as unilateral grading (Danielewicz \& Elbow, 2009).

The course was set up so that students were rewarded for meeting assignment criteria and turning the work in on time; if a student didn't meet the expectations of the assignment but did meet the due date, our professor offered them the opportunity to revise or redo the assignment so that it could meet the assignment expectations without penalizing their grade. Our grades were either marked complete or incomplete, and the syllabus explained that to get an A, we needed to get a complete mark on all major assignments and $90 \%$ of the minor assignments. Other scholars use similar but slightly different models of contract grading, one of the many benefits to implementing a contract into the grading criteria. A popular example is Peter Elbow's unilateral grading model, in which students are guaranteed a B in the course simply by attending class and turning in work, but must earn an A by exceeding expectations and producing quality work (Danielewicz \& Elbow, 2009).

Contract grading offers a safe and unique learning opportunity for students who otherwise, like me, get caught up in the intricacies of rubric requirements and possible teacher biases. I learned to stop thinking about my writing in terms of what my professor would want to read, and instead I began writing what I wanted to write. 
I was still putting forth the effort my professor was hoping for, but I knew that I could take risks without being punished for it.

Many scholars consider contract grading a method to engage fairness in the classroom (Mallette \& Hawks, 2020; Reardon \& Guardado-Menjivar, 2020). This is because it rewards students for participating in class and working on assignments, even if they don't quite reach the expectations the first time. "One of the central features of grading contracts is that they create exchange value for labor, guaranteeing minimum grades that correspond to completion of the work of a writing course" (Gomes et. al., 2020, p. 1). This grading method allowed students to make mistakes and learn from them, but it didn't exempt students from putting forth effort in the classroom. Instead, it seemed to promote student motivation. A large part of the reason contract grading seems to work so well in classroom settings is because it doesn't take responsibility off of the students or the teachers. We were still required to submit work by a deadline that met certain criteria, and our professor gave us feedback to let us know what we did well and what we needed to improve. We weren't afraid of failure in the classroom anymore; as long as we were willing to put in the work, we could take risks, learn from our mistakes, and end the course with a portfolio of quality assignments.

EN205 grew my confidence as a writer and student and shaped my student habits for the rest of my college experience. I'm no longer that scared high school senior who was afraid of failure because I was provided a classroom experience where I could fail safely, and as a result, I watched my writing go from the dreaded five paragraph essay writing to genuine prose. I still strive for As, but now I want to receive them because my professors like the writing I want to write, not because I write what my

Contract grading allows students to focus primarily on the process of learning, which reflects the phrase "It's not about the destination, it's about the journey." professors might want to read. I encourage professors to consider contract grading in their courses because it enforces student independence and allows them to learn from mistakes. As Elbow and Danielewicz (2009) note, "Even teachers who are not free to depart from a conventional grading system can experiment tentatively with a contract for only certain purposes, or for certain features of a course." Contract grading allows students to focus primarily on the process of learning, which reflects the phrase "It's not about the destination, it's about the journey." So many students, including myself, focus on the destination (the grade) rather than the journey (the act of learning). In my experience, unilateral grading not only allowed me to truly experience the journey of learning, but it taught me how to appreciate it in other classes as well. 


\section{References}

Danielewicz, J., \& Elbow, P. (2009). A unilateral grading contract to improve learning and teaching. College Composition and Communication, 61(2), 244-268. http://www.jstor.org/stable/4059344

Gomes, M., Bellati, B., Hope, M., \& LaFerriere, A. (2020). Enabling meaningful labor: Narratives of participation in a grading contract. Journal of Writing Assessment, 13(2), 1-11.

https://search.ebscohost.com/login.aspx?direct=true\&db=eue\&AN=14948262 4\&authtype $=$ sso\&custid $=083-900 \&$ site $=$ edslive\&scope $=$ site \&authtype $=$ sso\&custid $=083-900$

Mallette, J. C., \& Hawks, A. (2020). Building student agency through contract grading in technical communication. Journal of Writing Assessment, 13(2), 1-5.

https://search.ebscohost.com/login.aspx?direct=true\&db=eue\&AN=14948262 7\&authtype $=$ sso\&custid $=083-900 \&$ site $=$ edslive\&scope $=$ site \&authtype $=$ sso \&custid $=083-900$

Reardon, K., \& Guardado-Menjivar, V. (2020). Perceptions of fairness in summer bridge classrooms with contract grades. Journal of Writing Assessment, 13(2), $1-4$.

https://search.ebscohost.com/login.aspx?direct=true\&db=eue\&AN=14948262 6\&authtype $=$ sso\&custid $=083-900 \&$ site $=$ eds$\underline{\text { live \&scope }=\text { site \&authtype }=\text { sso\&custid }=083-900}$

Taylor Lucas graduated from Park University where she earned a BA in English, a minor in Organizational Communications, and is certified in Professional and Technical Writing. Throughout her student career, Taylor served as president of Park's chapter of Sigma Tau Delta, received the Mary Barlow Writing Award, and published several of her short stories in Park's student literary magazine, The Scribe. Her future hope is to become an editor, and she has taken the first step by gaining professional experience by serving as InSight's editorial intern during the 2021 spring semester. 